\title{
Mysteries of TGF- $\beta$ paradox in benign and malignant cells
}

\author{
Qiang Zhang ${ }^{1}$, Nengwang $\mathrm{Yu}^{2}$ and Chung Lee ${ }^{1,3,4,5 *}$ \\ 1 Department of Urology, Northwestern University School of Medicine, Chicago, IL, USA \\ 2 Department of Urology, General Hospital of Jinan Military Command, Jinan, China \\ ${ }^{3}$ Department of Surgery, NorthShore University HealthSystem, Evanston Hospital, Evanston, IL, USA \\ ${ }^{4}$ Department of Pathology and Laboratory Medicine, University of California at Irvine, Irvine, CA, USA \\ ${ }^{5}$ Department of Urology, University of California at Irvine, Irvine, CA, USA
}

Edited by:

Pilar Blancafort, The University of Western Australia, Australia

\section{Reviewed by:}

Robert Friis, University of Bern, Switzerland

Luisa Lanfrancone, European Institute of Oncology, Italy

\section{${ }^{*}$ Correspondence:}

Chung Lee, Northwestern University, 303 East Chicago Avenue, Tarry 16-733, Chicago, IL 60611, USA e-mail:c-lee7@northwestern.edu
TGF- $\beta$ regulates a wide range of biological functions including embryonic development, wound healing, organogenesis, immune modulation, and cancer progression. Interestingly, TGF- $\beta$ is known to inhibit cell growth in benign cells but promote progression in cancer cells; this phenomenon is known as TGF- $\beta$ paradox. To date, the mechanism of this paradox still remains a scientific mystery. In this review, we present our experience, along with the literature, in an attempt to answer this mystery. First, we observed that, on TGF- $\beta$ engagement, there is a differential activation of Erk between benign and cancer cells. Since activated Erk is a major mediator in tumor progression and metastasis, a differentially activated Erk represents the answer to this mystery. Second, we identified a key player, PP2A-B56 $\alpha$, which is differentially recruited by the activated type ITGF- $\beta$ receptor (TBRI) in benign and tumor cells, resulting in differential Erk activation. Finally, TGF- $\beta$ stimulation leads to suppressed TBRs in tumor cells but not in benign cells. This differentially suppressed TBRs triggers differential recruitment of PP2A-B56 $\alpha$ and, thus, differential activation of Erk. The above three events explain the mysteries of TGF- $\beta$ paradox. Understanding the mechanism of TGF- $\beta$ paradox will help us to predict indolent from aggressive cancers and develop novel anti-cancer strategies.

Keywords:TGF- $\beta$ paradox, TGF- $\beta$ receptors, Erk activation, Smad activation, PP2A recruitment,TGF- $\beta$ auto-induction, negative feedback, positive feedback

\section{INTRODUCTION}

TGF- $\beta$ was initially described in 1982 (1). It was already known to have bi-functional effects, as it can stimulate or inhibit growth of the same cell, depending on conditions (2). These initial reports have demonstrated the mysterious and important nature of TGF- $\beta$ in physiology and pathology. More than 40 years later, our understanding of TGF- $\beta$ signaling has greatly expanded and TGF- $\beta$ is known as an important mediator in cancer progression. In this review, we provide insights into the mystery of the well-known phenomenon of "TGF- $\beta$ paradox," mainly based on our own experience, along with the literature information. It should be pointed out that this report is limited to few salient aspects of TGF- $\beta$ signaling relevant to the present discussion. For a more comprehensive description of TGF- $\beta$ signaling, please refer to our recent review (3).

\section{BIOLOGY OF TGF- $\beta$ SIGNALING}

There are three known mammalian isoforms of TGF- $\beta$ (TGF- $\beta 1$, $-\beta 2$, and $-\beta 3$ ) with significant structural and functional similarity (4). The biological effect of TGF- $\beta$ is mediated through type I and type II receptors (TBRI and TBRII) (5). The canonical downstream events involve the activation of Smad pathways (6). TGF- $\beta$ first binds to TBRII, which recruits and activates TBRI $(5,7)$. The latter then activates $S m a d 2 / 3$. The activated $S m a d 2 / 3$ combines with Smad4 and migrates to the nucleus to regulate transcription (8). In addition to the Smad pathway, TGF- $\beta$ also signals through a number of non-canonical pathways, including m-TOR, RhoA,
Ras, MAPK, PI3K/AKT, PP2A/p70s6K, and JNK (9). The relative importance and interplay of these pathways of TGF- $\beta$ signaling is still under investigation $(10,11)$. In this review, we will limit our discussion to TGF- $\beta$-mediated Smad and Erk activation.

\section{TGF- $\beta$ PARADOX}

TGF- $\beta$ is known to inhibit cell cycle in benign cells but promote progression and metastasis in cancer cells $(3,12)$, a phenomenon known as TGF- $\beta$ paradox (13). Although there are numerous articles with different approaches tackling this topic, to date, a logical explanation leading to TGF- $\beta$ paradox remains elusive and is accepted as a scientific mystery $(3,13-15)$. In this study, we searched the recent literature, along with our own experience, in an attempt to explain this mystery.

\section{MYSTERY OF TGF- $\beta$ PARADOX 1 DIFFERENTIAL ACTIVATION OF ERK BETWEEN BENIGN AND CANCER CELLS}

It is well-known that TGF- $\beta$ is able to activate Erk in cancer cells (16-18) and inactivate Erk in non-cancer cells (19). However, a direct link of TGF- $\beta$-mediated differential activation of Erk between cancer and non-cancer cells in the same cell system has not been reported until our recent report (20), where we treated benign cells with a low concentration of TGF- $\beta(0.1 \eta \mathrm{g} / \mathrm{ml})$, which led to Erk activation; while the treatment of the same cells with a high concentration of TGF- $\beta(10 \eta \mathrm{g} / \mathrm{ml})$ resulted in Erk inactivation. Activated Erk is a key regulator for cell proliferation. 


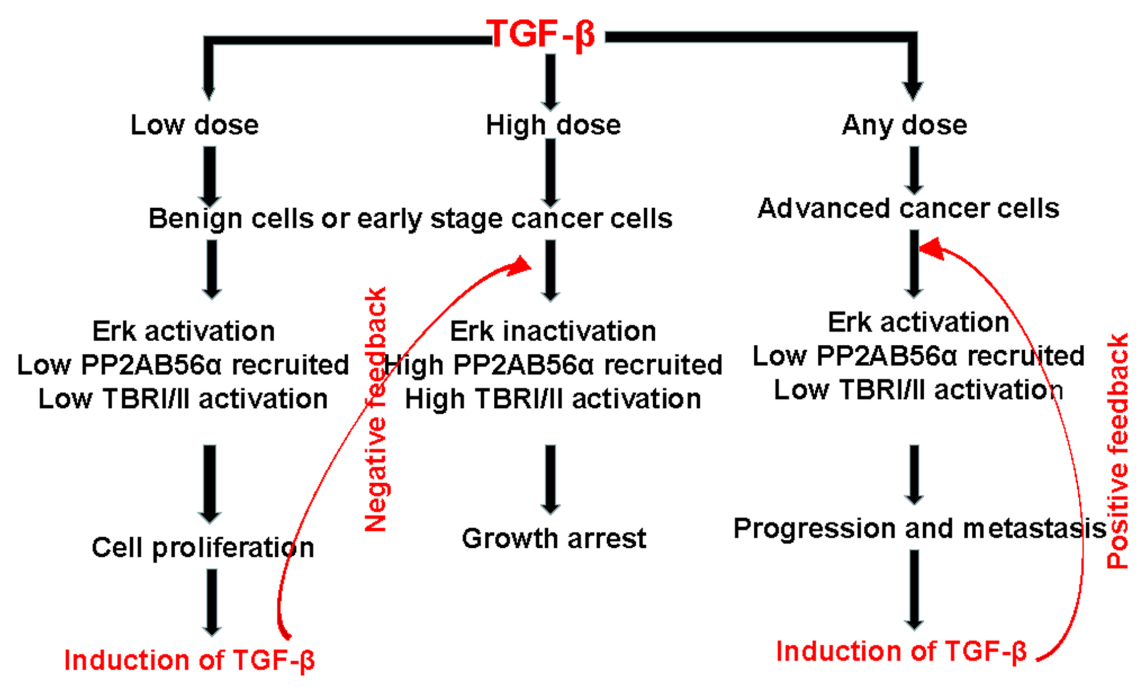

FIGURE 1 |A proposed mechanism to explain the TGF- $\beta$ paradox between benign and tumor cells. First, in benign cells, a low dose of TGF- $\beta$ in the microenvironment will result in Erk activation and cell proliferation. At the same time, there will be an auto-induction of TGF- $\beta$, which will create a high dose of TGF- $\beta$ in the microenvironment and lead to growth arrest. Therefore, the level of TGF- $\beta$ is regulated via a negative feedback loop. On the other hand, in cancer cells, Erk will be activated regardless of the level of TGF- $\beta$ in the microenvironment. The activated Erk is a master regulator of tumor progression and metastasis. It will also auto-induce more TGF- $\beta$, which will create a positive feedback of TGF- $\beta$ signaling in tumor progression. The level of TGF- $\beta$ is regulated via a positive feedback loop.
Consistent with this finding, we have observed cell proliferation in benign cells with a low dose of TGF- $\beta$ but growth arrest with a high dose in benign stromal cells (21) as well as in benign epithelial cells (17). The use of different dosages of TGF- $\beta$ in these studies is critical as they bring out the interesting phenomenon of differential responses to TGF- $\beta$ stimulation. It should be pointed out that cancer cells in the early stage of carcinogenesis retain some of the features of benign cells in which they can be inhibited by TGF- $\beta$ $(22,23)$. However, in advanced cancer cells, treatment with TGF- $\beta$ would result in Erk activation and cell proliferation $(16,17,21,24)$.

The above explanation to TGF- $\beta$ paradox is summarized in Figure 1. An important point is that, in contrast to the traditional concept of TGF- $\beta$ paradox $(13,17)$, TGF- $\beta$ treatment in benign cells does not always result in growth arrest. Figure 1 indicates that under normal physiological conditions, cellular activities are carefully monitored by TGF- $\beta$. Differential Erk activation seems to play a central role in this regulation. When TGF- $\beta$ level in the local environment is low, cells will activate Erk and induce TGF- $\beta$ expression (20). On the other hand, when the local concentration of TGF- $\beta$ is more than sufficient, cells have a mechanism to shut off Erk activation, thus, prevent further expression of TGF- $\beta$.

It is important to note that Erk activation or inactivation by TGF- $\beta$ in benign cells is not a case of all-or-none phenomenon. In order to demonstrate the gradual changes in Erk or Smad activation in benign cells, multiple doses of TGF- $\beta$ at different cell density must be employed as described by Clarke et al. (25). Indeed, they demonstrated a linear increment of Smad activation within a wide range of available TGF- $\beta$ per cell in mink lung epithelial cells (25). In an attempt to validate the same linear relationship exists between TGF- $\beta$ dosage and Erk inactivation, we repeated the same experiment performed by Clarke et al. (25) by using a different set of benign epithelial cells (RWPE1 and BPH1). Indeed, a linear
Erk inactivation was demonstrated (Figure 2). This phenomenon is applied only to benign cells or early-stage cancer cells, as in advanced cancer cells, there will be no such linear relationship in Smad activation and Erk inactivation upon TGF- $\beta$ stimulation. In advanced cancer cells, Erk is constantly in an activated state (17, 20) and Smad activation is suppressed, regardless of the level of TGF- $\beta$ employed. This finding has an important implication in TGF- $\beta$ paradox, that is, in benign cells or early stage cancer cells, TGF- $\beta$ offers a mechanism for homeostasis; whereas in advanced cancer cells, it promotes tumor progression (Figure 1).

\section{MYSTERY OF TGF- $\beta$ PARADOX 2}

\section{DIFFERENTIAL RECRUITMENT OF PP2A-B56 $\alpha$ BY ACTIVATED TBRI}

The observation of a differentially activated Erk between benign and cancer cells offers an explanation to the mystery of TGF- $\beta$ paradox (Figure 1). The question remains as how the differentially activated Erk is regulated? Our recent observation has identified a key player, PP2A-B56 $\alpha$ (subunit B56 $\alpha$ of protein phosphatase $2 \mathrm{~A}$ ), which plays a pivotal role in the regulation of differentially activated Erk between benign and cancer cells upon TGF- $\beta$ engagement (20). PP2A is a known tumor suppressor $(26,27)$ and is involved in a broad range of cellular processes, including signal transduction, transcriptional regulation, and control of the cell cycle. The PP2A holoenzyme is a heterotrimer that consists of a core dimer, which has scaffold (A) and catalytic (C) subunits that associate with a variety of regulatory (B) subunits. PP2A-A brings the PP2A-B and -C subunits together. PP2A-C performs the enzymatic reaction, while $\mathrm{PP} 2 \mathrm{~A}-\mathrm{B}$ is responsible to direct the cellular localization and site specificity. The B subunits have been divided into gene families named B (or PR55), B' (or B56 or PR61), and B" (or PR72) (28). These B subunits determine the substrate specificity as well as the spatial and temporal functions of PP2A (28). 


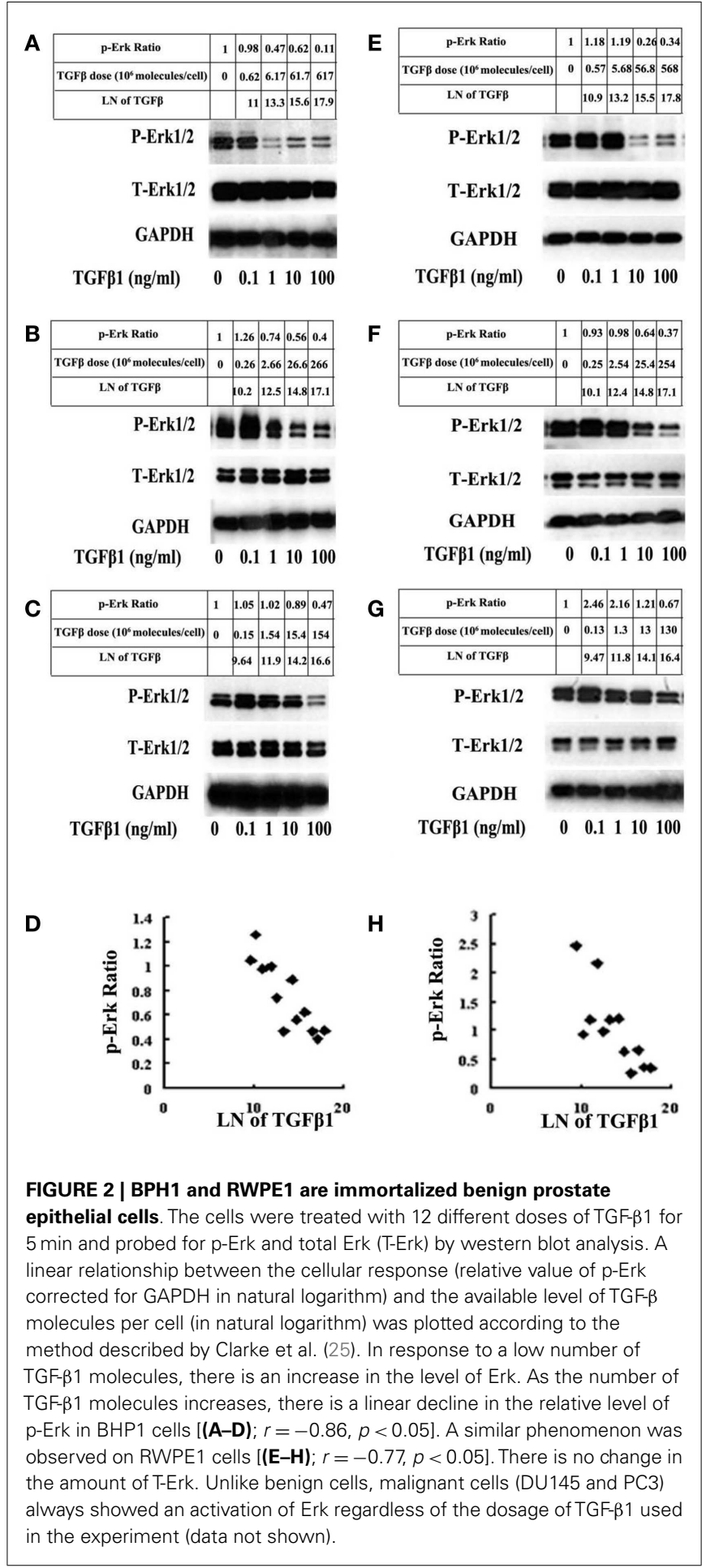

The B56 family consists of $\mathrm{B} 56 \alpha, \beta, \gamma, \delta$, and $\varepsilon$, generating at least eight isoforms (28).

TGF- $\beta$ is known to activate PP2A-B $\alpha$ in benign cells (26). Only recently, we and others have observed a differential recruitment of PP2A-B56 $\alpha$ (but not other PP2As) by the activated TBRI in benign and cancer cells $(20,29)$. Upon TGF- $\beta$ treatment in benign cells, TBRII is able to recruit and activate TBRI $(5,7)$. We found that
PP2A-B56 $\alpha$ was able to be co-precipitated with the activated TBRI in benign cells in large quantities, leading to inactivation of Erk (20). But in cancer cells, since there is a limited available amount of activated TBRI (30), a limited or no PP2A-B56 $\alpha$ was able to be co-precipitated with TBRI, resulting in activation of Erk $(20,31)$. PP2A is ubiquitously synthesized but is specifically recruited and activated by the activated TBRI to function as an inhibitor to Erk activation (20,31). This observation was independently validated by others using a different cell system (29).

A key event in TGF- $\beta$ paradox is the recruitment of PP2AB56 $\alpha$ by the activated TBRI $(20,29)$. In benign cells, PP2A-B56 $\alpha$ is recruited by the activated TBRI, which is dependent on the dosage of TGF- $\beta$ used to stimulate the target cells. At a high dose of TGF$\beta$, a sufficient quantity of PP2A-B56 $\alpha$ is recruited by the activated TBRI, resulting in an inhibition of Erk activation; while at a low dose of TGF- $\beta$, due to a limited quantity of TBRI being activated, there will be a limited quantity of PP2A-B56 $\alpha$ to be recruited resulting in Erk activation. In the context of advanced cancer cells, due to a severely down-regulated TBRI (30), recruitment of PP2AB56 $\alpha$ is always compromised regardless of the dosage of TGF- $\beta$ employed, resulting in an elevated activation of Erk (20). This PP2A-B56 $\alpha$-mediated differential Erk activation between benign and malignant cells offers an answer to the mystery of TGF- $\beta$ paradox.

\section{MYSTERY OF TGF- $\beta$ PARADOX 3 DIFFERENTIAL SUPPRESSION OF TBRS AND AUTO-INDUCTION OF TGF- $\beta$}

Finally, we ask what are the triggering factor and the consequence of the observed differentiated Erk activation in TGF- $\beta$ paradox. We conclude that the downregulation of TBRs is the triggering factor and the over expression of TGF- $\beta$ is the consequence of the TGF- $\beta$ paradox (15). Both events have important implications.

It is well-known that, in advanced cancer cells, TGF- $\beta$ mediates downregulation of TBRs and auto-induction of TGF- $\beta$ in cancer cells but not in benign cells (31-34). Since the activated Erk is a master regulator for tumor progression (16), it is responsible for a host of oncogenic signaling events including NF- $\mathrm{KB}$ activation, which up-regulates DNA methyltransferases (DNMTs) (35). Targets of DNMTs promoter methylation in many tumor suppressor genes are TBRs $(34,35)$. A search of the literature has revealed that downregulation of TBRs is an early event of carcinogenesis for all types of cancer (36). The biological consequence of a downregulated TBR will be an attenuate $S \operatorname{mad} 2 / 3$ activation and an elevated Erk $1 / 2$ activation in advanced cancer cells. The availability of TBRs dictates the relative levels of activated Erk1/2 and inactivated Smad $2 / 3$, thus determines the fate of the TGF- $\beta$ paradox (25, $37,38)$. It follows that any condition that results in downregulation of functional TBRs, such as inflammation $(39,40)$, Ras activation $(41,42)$, and loss-of-function mutations in TBRs $(43-45)$, will be predisposed to development and progression of cancer.

TGF- $\beta$ overproduction is also an universal event in cancer cells and is a poor prognostic marker $(20,35,46-49)$. The mechanism, although which TGF- $\beta$ regulates its own production, is different between benign and cancer cells. Under the normal physiological conditions, the level of TGF- $\beta$ is tightly regulated within the microenvironment through a negative feedback loop (Figure 1) to 
maintain a relatively constant level of TGF- $\beta$. Too little or too much TGF- $\beta$ will have an unfavorable consequence $(36,50,51)$. However, this principle does not apply to cancer. Cancer cells, especially the advanced cases, are capable of evading the immune surveillance program due to the well-known phenomenon of auto-induction of TGF- $\beta$ by cancer cells (20), resulting in an elevated TGF- $\beta$ in the microenvironment through a positive feedback loop (52). As a result, there is an accumulation of TGF- $\beta$ in the microenvironment, which further promotes tumor progression $(20,35,48)$. Therefore, with regard to TGF- $\beta$ signaling, a characteristic feature of cancer cells, as opposed to the benign cells, is suppressed TBRs (the cause) and an elevated TGF- $\beta$ (the effect). This feature applies to all cancer cells and can be used as a biomarker for prediction of aggressiveness of the cancer $(17,35)$.

\section{CONCLUSION}

\section{POSITIVE FEEDBACK OF TGF- $\beta$ SIGNALING IN TUMOR PROGRESSION}

In summary, this review indicates that a differential Erk activation plays a central role in deciding whether the target cell will undergo growth arrest or proliferation in response to TGF- $\beta$. In addition, the description of the conventional concept of "TGF$\beta$ Paradox" (12-15) may require a slight modification. First, the term TGF- $\beta$ paradox does not imply that TGF- $\beta$ inhibits cell cycle in benign cells. As indicated in this review, benign cells can also be stimulated by TGF- $\beta$ to undergo proliferation, if the dose of TGF- $\beta$ is low. Furthermore, cancer cells can be inhibited by TGF$\beta$, especially in the early stages of carcinogenesis, if a sufficient level of TBRs can be activated (Figure 1). Therefore, we conclude that a more appropriate interpretation for TGF- $\beta$ paradox should be that TGF- $\beta$ mediates cellular homeostasis in benign cells but promotes tumor progression and metastasis in advanced cancer cells. Second, the term of TGF- $\beta$ paradox does not imply an allor-none phenomenon $(13,17)$. In fact, the changes in target cells in the level of Erk1/2 activation or Smad2/3 inactivation mediated by TGF- $\beta$ are gradual depending on the relative levels of TGF- $\beta$ present available per cell in the local microenvironment [Ref. (25), Figure 2]. Also, TGF- $\beta$-mediated changes in cell proliferation or growth arrest takes place in a gradual manner depending on the dosage of TGF- $\beta$ employed $(20,35)$.

The consequence of Erk activation in cancer cells can result in a continuous TGF- $\beta$ auto-induction via a positive feedback loop (Figure 1). This continuous production of TGF- $\beta$ in the tumor microenvironment will further stimulate tumor progression and metastasis resulting in the manifestation of the development of a more aggressive tumor progression. The implications of this positive feedback of TGF- $\beta$ signaling in tumor progression are at least twofold. First, this knowledge can be used for the prediction of cancer outcome in that TGF- $\beta$ content in the tumor can be used to predict whether or not the tumor in question is indolent or aggressive $(17,35)$. Second, due to the knowledge that TGF- $\beta$ in the tumor microenvironment is highly immune-suppressive (53), it will be important to render the cytotoxic cells insensitive to TGF- $\beta$ in cancer immunotherapy (54).

\section{ACKNOWLEDGMENTS}

This research was supported by the following grants: NCI SPORE P50-CA90386, NCI EDRN U01-CA152738, NCI SPECS U01-CA114810, and DOD W81XWH-09-1-0311.

\section{REFERENCES}

1. Anzano MA, Roberts AB, Meyers CA, Komoriya A, Lamb LC, Smith JM, et al. Synergistic interaction of two classes of transforming growth factors from murine sarcoma cells. Cancer Res (1982) 42:4776-8.

2. Roberts AB, Anzano MA, Wakefield LM, Roche NS, Stern DF, Sporn MB. Type beta transforming growth factor: a bifunctional regulator of cellular growth. Proc Natl Acad Sci U S A (1985) 82:119-23. doi:10.1073/pnas. 82.1.119

3. Principe DR, Doll JA, Bauer J, Jung B, Munshi HG, Bartholin L, et al. TGF- $\beta$ : duality of function between tumor prevention and carcinogenesis. J Natl Cancer Inst (2014) 106:djt369. doi:10.1093/jnci/djt369

4. Patil AS, Sable RB, Kothari RM. An update on transforming growth factor- $\beta$ (TGF- $\beta$ ): sources, types, functions and clinical applicability for cartilage/bone healing. J Cell Physiol (2011) 226:3094-103. doi:10.1002/jcp.22698

5. Massagué J, Gomis RR. The logic of TGF- $\beta$ signaling. FEBS Lett (2006) 580:2811-20. doi:10.1016/j.febslet.2006.04.033

6. Shi Y, Massagué J. Mechanisms of TGF- $\beta$ signaling from cell membrane to the nucleus. Cell (2003) 113:685-700. doi:10.1016/S0092-8674(03)00432-X

7. Derynck R, Akhurst RJ, Balmain A. TGF-beta signaling in tumor suppression and cancer progression. Nat Genet (2001) 29:117-29. doi:10.1038/ ng1001- 117

8. Vogelmann R, Nguyen-Tat MD, Giehl K, Adler G, Wedlich D, Menke A. TGF$\beta$ induced downregulation of E-cadherin-based cell-cell adhesion depends on PI3-kinase and PTEN. J Cell Sci (2005) 118:4901-12. doi:10.1242/jcs.02594

9. Mu Y, Gudey SK, Landström M. Non-Smad signaling pathways. Cell Tissue Res (2012) 347:11-20. doi:10.1007/s00441-011-1201-y

10. Miyazono K. Transforming growth factor-beta signaling in epithelialmesenchymal transition and progression of cancer. Proc Jpn Acad Ser B Phys Biol Sci (2009) 85:314-23. doi:10.2183/pjab.85.314

11. Gomes LR, Terra LF, Wailemann RA, Labriola L, Sogayar MC. TGF- $\beta 1$ modulates the homeostasis between MMPs and MMP inhibitors through p38 MAPK and ERK1/2 in highly invasive breast cancer cells. BMC Cancer (2012) 19(12):26. doi:10.1186/1471-2407-12-26

12. Inman GJ. Switching TGF $\beta$ from a tumor suppressor to a tumor promoter. Curr Opin Genet Dev (2011) 21:93-9. doi:10.1016/j.gde.2010.12.004

13. Morrison CD, Parvani JG, Schiemann WP. The relevance of the TGF- $\beta$ paradox to EMT-MET programs. Cancer Lett (2013) 341:30-40. doi:10.1016/j.canlet. 2013.02.048

14. Ranganathan P, Agrawal A, Bhushan R, Chavalmane AK, Kalathur RK, Takahashi $\mathrm{T}$, et al. Expression profiling of genes regulated by TGF-beta: differential regulation in normal and tumour cells. BMC Genomics (2007) 8:98. doi:10.1186/1471-2164-8-98

15. Chung SW, Cooper CR, Farach-Carson MC, Ogunnaike BA. A control engineering approach to understanding the TGF-â paradox in cancer. $J$ R Soc Interface (2012) 9:1389-97. doi:10.1098/rsif.2011.0799

16. Lee MK, Pardoux C, Hall MC, Lee PS, Warburton D, Qing J, et al. TGF-beta activates Erk MAP kinase signalling through direct phosphorylation of ShcA. EMBO J (2007) 26:3957-67. doi:10.1038/sj.emboj.7601818

17. Zhang Q, Helfand BT, Jang TL, Zhu LJ, Chen L, Yang XJ, et al. NF-kB-mediated transforming growth factor- $\beta$-induced expression of vimentin is an independent predictor of biochemical recurrence after radical prostatectomy. Clin Cancer Res (2009) 15:3557-67. doi:10.1158/1078-0432.CCR-08-1656

18. Iwanaga R, Wang CA, Micalizzi DS, Harrell JC, Jedlicka P, Sartorius CA, et al. Expression of Sixl in luminal breast cancers predicts poor prognosis and promotes increases in tumor initiating cells by activation of extracellular signalregulated kinase and transforming growth factor-beta signaling pathways. Breast Cancer Res (2012) 14:R100. doi:10.1186/bcr3219

19. Luo X, Zhang Q, Liu V, Xia Z, Pothoven KL, Lee C. Cutting edge: TGF-betainduced expression of Foxp 3 in T cells is mediated through inactivation of ERK. J Immunol (2008) 180:2757-61. doi:10.4049/jimmunol.180.5.2757

20. Yu N, Kozlowski JM, Park II, Chen L, Zhang Q, Xu D, et al. Over-expression of transforming growth factor $\beta 1$ in malignant prostate cells is partly caused by a runaway of TGF- $\beta 1$ auto-induction mediated through a defective recruitment of protein phosphatase 2A by TGF- $\beta$ type I receptor. Urology (2010) 76: 1519.e8-13. doi:10.1016/j.urology.2010.03.061

21. Zhou W, Park I, Pins M, Kozlowski JM, Jovanovic B, Zhang J, et al. Dual regulation of proliferation and growth arrest in prostatic stromal cells by transforming growth factor- $\beta 1$. Endocrinology (2003) 144:4280-4. doi:10.1210/en. 2003-0554 
22. Yamazaki K, Masugi Y, Sakamoto M. Molecular pathogenesis of hepatocellular carcinoma: altering transforming growth factor-â signaling in hepatocarcinogenesis. Dig Dis (2011) 29:284-8. doi:10.1159/000327560

23. Kowli S, Velidandla R, Creek KE, Pirisi L. TGF- $\beta$ regulation of gene expression at early and late stages of HPV16-mediated transformation of human keratinocytes. Virology (2013) 447:63-73. doi:10.1016/j.virol.2013.08.034

24. Gore AJ, Deitz SL, Palam LR, Craven KE, Korc M. Pancreatic cancer-associated retinoblastoma 1 dysfunction enables TGF- $\beta$ to promote proliferation. J Clin Invest (2014) 124:338-52. doi:10.1172/JCI71526

25. Clarke DC, Brown ML, Erickson RA, Shi Y, Liu X. Transforming growth factor beta depletion is the primary determinant of Smad signaling kinetics. Mol Cell Biol (2009) 29:2443-55. doi:10.1128/MCB.01443-08

26. Petritsch C, Beug H, Balmain A, Oft M. TGF- $\beta$ inhibits p70 S6 kinase via protein phosphatase 2A to induced G1 arrest. Genes Develop (2000) 14:3093-101. doi:10.1101/gad.854200

27. Khanna A, Kauko O, Böckelman C, Laine A, Schreck I, Partanen JI, et al. Chk1 targeting reactivates PP2A tumor suppressor activity in cancer cells. Cancer Res (2013) 73:6757-69. doi:10.1158/0008-5472.CAN-13-1002

28. McCright B, Rivers AM, Audlin S, Virshup DM. The B56 family of protein phosphatase $2 \mathrm{~A}(\mathrm{PP} 2 \mathrm{~A})$ regulatory subunits encodes differentiation-induced phosphoproteins that target PP2A to both nucleus and cytoplasm. J Biol Chem (1996) 271:22081-9. doi:10.1074/jbc.271.36.22081

29. Samuel GH, Bujor AM, Nakerakanti SS, Hant FN, Trojanowska M. Autocrine transforming growth factor $\beta$ signaling regulates extracellular signal-regulated kinase $1 / 2$ phosphorylation via modulation of protein phosphatase $2 \mathrm{~A}$ expression in scleroderma fibroblasts. Fibrogenesis Tissue Repair (2010) 3:25. doi:10. 1186/1755-1536-3-25

30. Zhang Q, Rubenstein JN, Jang TL, Pins M, Javonovic B, Yang X, et al. Insensitivity to transforming growth factor- $\beta$ signaling is resulted from promoter methylation of cognate receptors in human prostate cancer cells (LNCaP). Mol Endocrinol (2005) 19:2390-9. doi:10.1210/me.2005-0096

31. Letourneux C, Rocher G, Porteu F. B56-containing PP2A dephosphorylate ERK and their activity is controlled by the early gene IEX-1 and ERK. EMBO J (2006) 25:727-38. doi:10.1038/sj.emboj.7600980

32. Lee C, Sintich SM, Mathews EP, Shah AH, Kundu SD, Perry KT, et al. Transforming growth factor- $\beta$ in benign and malignant prostate. Prostate (1999) 39:285-90. doi:10.1002/(SICI) 1097-0045(19990601)39:4<285::AID-PROS9> 3.0.CO;2-7

33. Kim SJ, Angel P, Lafyatis R, Hattori K, Kim KY, Sporn MB, et al. Autoinduction of transforming growth factor beta 1 is mediated by the AP- 1 complex. Mol Cell Biol (1990) 10:1492-7.

34. Halder SK, Cho YJ, Datta A, Anumanthan G, Ham AJ, Carbone DP, et al. Elucidating the mechanism of regulation of transforming growth factor $\beta$ type II receptor expression in human lung cancer cell lines. Neoplasia (2011) 13:912-22. doi:10.1593/neo.11576

35. Zhang Q, Chen L, Helfand BT, Zhu LJ, Kozlowski J, Minn A, et al. Transforming growth factor- $\beta$-induced DNA methyltransferase contributes to aggressive prostate cancer phenotypes and predicts biochemical recurrence after radical prostatectomy. PLoS One (2011) 6:e25168. doi:10.1371/journal.pone. 0025168

36. Singh N, Liu G, Chakrabarty S. Cellular responses to TGF $\beta$ and TGF $\beta$ receptor expression in human colonic epithelial cells require CaSR expression and function. Cell Calcium (2013) 53:366-71. doi:10.1016/j.ceca.2013.04.003

37. Nickl-Jockschat T, Arslan F, Doerfelt A, Bogdahn U, Bosserhoff A, Hau P. An imbalance between Smad and MAPK pathways is responsible for TGF-beta tumor promoting effects in high-grade gliomas. Int J Oncol (2007) 30:499-507. doi:10.3892/ijo.30.2.499

38. Briones-Orta MA, Tecalco-Cruz AC, Sosa-Garrocho M, Caligaris C, Macías-Silva M. Inhibitory Smad7: emerging roles in health and disease. Curr Mol Pharmacol (2011) 4:141-53. doi:10.2174/1874-470211104020141

39. Bohrer LR, Schwertfeger KL. Macrophages promote fibroblast growth factor receptor-driven tumor cell migration and invasion in a CXCR2-dependent manner. Mol Cancer Res (2012) 10:1294-305. doi:10.1158/1541-7786.MCR-120275

40. Achyut BR, Bader DA, Robles AI, Wangsa D, Harris CC, Ried T, et al. Inflammation-mediated genetic and epigenetic alterations drive cancer development in the neighboring epithelium upon stromal abrogation of TGF- $\beta$ signaling. PLoS Genet (2013) 9:e1003251. doi:10.1371/journal.pgen.1003251

41. Ijichi H, Chytil A, Gorska AE, Aakre ME, Fujitani Y, Fujitani S, et al. Aggressive pancreatic ductal adenocarcinoma in mice caused by pancreas-specific blockade of transforming growth factor-beta signaling in cooperation with active Kras expression. Genes Dev (2006) 20:3147-60. doi:10.1101/gad.1475506

42. Trobridge P, Knoblaugh S, Washington MK, Munoz NM, Tsuchiya KD, Rojas A, et al. TGF-beta receptor inactivation and mutant Kras induce intestinal neoplasms in mice via a beta-catenin-independent pathway. Gastroenterology (2009) 136: 1680-8.e7. doi:10.1053/j.gastro.2009.01.066

43. Lu SL, Kawabata M, Imamura T, Miyazono K, Yuasa Y. Two divergent signaling pathways for TGF-beta separated by a mutation of its type II receptor gene. Biochem Biophys Res Commun (1999) 259:385-90. doi:10.1006/bbrc.1999. 0788

44. Chen T, Yan W, Wells RG, Rimm DL, McNiff J, Leffell D, et al. Novel inactivating mutations of transforming growth factor-beta type I receptor gene in head-andneck cancer metastases. Int J Cancer (2001) 93:653-61. doi:10.1002/ijc.1381

45. Bellam N, Pasche B. TGF-beta signaling alterations and colon cancer. Cancer Treat Res (2010) 155:85-103. doi:10.1007/978-1-4419-6033-7_5

46. Van Belle P, Rodeck U, Nuamah I, Halpern AC, Elder DE. Melanoma-associated expression of transforming growth factor-beta isoforms. Am J Pathol (1996) 148:1887-94

47. Wikström P, Stattin P, Franck-Lissbrant I, Damber JE, Bergh A. Transforming growth factor betal is associated with angiogenesis, metastasis, and poor clinical outcome in prostate cancer. Prostate (1998) 37:19-29. doi:10.1002/(SICI)10970045(19980915)37:1<19::AID-PROS4>3.0.CO;2-3

48. Berking C, Takemoto R, Schaider H, Showe L, Satyamoorthy K, Robbins P, et al. Transforming growth factor-betal increases survival of human melanoma through stroma remodeling. Cancer Res (2001) 61:8306-16.

49. Vázquez PF, Carlini MJ, Daroqui MC, Colombo L, Dalurzo ML, Smith DE, et al. TGF-beta specifically enhances the metastatic attributes of murine lung adenocarcinoma: implications for human non-small cell lung cancer. Clin Exp Metastasis (2013) 30:993-1007. doi:10.1007/s10585-013-9598- 1

50. Mamura M, Lee W, Sullivan TJ, Felici A, Sowers AL, Allison JP, et al. CD28 disruption exacerbates inflammation in Tgf-betal-/- mice: in vivo suppression by CD4+CD25+ regulatory T cells independent of autocrine TGF-beta1. Blood (2004) 103:4594-601. doi:10.1182/blood-2003-08-2897

51. Garcia-Lazaro JF, Thieringer F, Lüth S, Czochra P, Meyer E, Renteria IB, et al. Hepatic over-expression of TGF-betal promotes LPS-induced inflammatory cytokine secretion by liver cells and endotoxemic shock. Immunol Lett (2005) 101:217-22. doi:10.1016/j.imlet.2005.06.003

52. Connolly EC, Freimuth J, Akhurst RJ. Complexities of TGF- $\beta$ targeted cancer therapy. Int J Biol Sci (2012) 8:964-78. doi:10.7150/ijbs.4564

53. Matthews E, Yang T, Janulis L, Goodwin S, Kundu SD, Karpus WJ, et al. Down regulation of TGF- $\beta 1$ production restores immunogenicity in prostate cancer cells. Br J Cancer (2000) 83:519-25. doi:10.1054/bjoc.2000.1257

54. Zhang Q, Yang X, Pins M, Javonovic B, Kuzel T, Kim SJ, et al. Adoptive transfer of tumor reactive TGF- $\beta$ insensitive $C D 8^{+} \mathrm{T}$ cells: eradication of autologous mouse prostate cancer. Cancer Res (2005) 65:1761-9. doi:10.1158/0008-5472. CAN-04-3169

Conflict of Interest Statement: The authors declare that the research was conducted in the absence of any commercial or financial relationships that could be construed as a potential conflict of interest.

Received: 06 March 2014; accepted: 16 April 2014; published online: 13 May 2014. Citation: Zhang Q, Yu N and Lee C (2014) Mysteries of TGF- $\beta$ paradox in benign and malignant cells. Front. Oncol. 4:94. doi: 10.3389/fonc.2014.00094

This article was submitted to Molecular and Cellular Oncology, a section of the journal Frontiers in Oncology.

Copyright (C) 2014 Zhang, Yu and Lee. This is an open-access article distributed under the terms of the Creative Commons Attribution License (CC BY). The use, distribution or reproduction in other forums is permitted, provided the original author(s) or licensor are credited and that the original publication in this journal is cited, in accordance with accepted academic practice. No use, distribution or reproduction is permitted which does not comply with these terms. 